\title{
Subjects of Triumph and Literary History: Dido and Petrarch in Petrarch's Africa and Trionfi
}

\section{Citation}

Simpson, James. 2005. Subjects of triumph and literary history: Dido and Petrarch in Petrarch's Trionfi and Africa. Journal of Medieval and Early Modern Studies 35(3): 489-508.

\section{Published Version}

http://dx.doi.org/10.1215/10829636-35-3-489

\section{Permanent link}

http://nrs.harvard.edu/urn-3:HUL.InstRepos:2656859

\section{Terms of Use}

This article was downloaded from Harvard University's DASH repository, and is made available under the terms and conditions applicable to Other Posted Material, as set forth at http:// nrs.harvard.edu/urn-3:HUL.InstRepos:dash.current.terms-of-use\#LAA

\section{Share Your Story}

The Harvard community has made this article openly available.

Please share how this access benefits you. Submit a story.

Accessibility 
Subjects of Triumph and Literary History: Dido and Petrarch in Petrarch's Africa and Trionfi

Petrarch is much admired as the "first Renaissance man." In this tenacious account, Petrarch is said to initiate the Renaissance with his truly historical consciousness, his correlative attempt to imitate classical style, and with his representation of the self as divided. ${ }^{1}$ The fullest, most subtle and fairly recent example of this still vibrant tradition is Thomas Greene's The Light in Troy. Here Petrarch is given pride of place as the first writer to express the "historical solitude" of a European writer who feels tragically cut off and isolated from the unredeemable glory of classical civilization, and who nevertheless attempts to diminish that solitude by creative imitation of classical models. ${ }^{2}$ The mark of truly creative, what Greene calls "heuristic imitation," as distinct from a servile imitation, is the capacity to create a sense of historical distance. Petrarch's capacity to diminish historical distance is, that is, measured by his capacity to create it. ${ }^{3}$

In this essay I examine this triumphalist account of Petrarch as Renaissance man, by looking to Petrarch's own work of triumphs, the Trionfi. This work narrates the triumphs of, successively, Cupid, Chastity, Death, Fame, Time and Eternity. I concentrate on the first two 
triumphs, those of Cupid and Chastity (Triumphus

Cupidinis and Triumphus Pudicitiae), which were most probably written as a pair in the first conception of the triumphs, and begun, most probably, in 1352, the season before Petrarch's first stay in Milan, under Visconti patronage. ${ }^{4}$

My argument contributes to the revisionist critique of humanism recently mounted by some Early modernists and medievalists. ${ }^{5}$ I argue that, in the first two triumphs, Petrarch does indeed shape a new sense of literary history and practice. So far from being a liberating rediscovery of classical civilisation, however, I argue instead that literary history is rather generated out of imprisonment, subjection and pain. Petrarch joins an elite tradition, but he can do so only by absorbing the painful and punishing disciplines of that imprisoned elite. The pain of literary history is written into the very form of the triumphs, whose most characteristic feature is the glancing literary allusion, an allusion most often to a moment of searing and spectacular pain. Literary history takes shape here as the witness to recurrent subjections to an imperial, triumphal power. In order to generate this account, Petrarch must first, so I argue, reshape his Ovidian inheritance. This redirection of Ovid is most urgently a redirection of the narrative of Dido, the most troubling and resurgent 
narrative in the triumphs of Cupid and Chastity. In literary history Dido's unbearable, suicidal fate as Aeneas' victim stands as the most powerful objection to imperial ideology. Before Petrarch can reinstate Virgilian epic models, he must both erase the troubling Dido narrative, and he must discipline Ovid. Whereas Ovid is the great subverter of imperial, heroic poetry, Petrarch seeks to close the gap between Ovidian elegy and Virgilian epic. Accordingly, I start with Petrarch's reworkings of the Dido narrative, and move from there to the implications of that reworking for Petrarchan literary history.

Petrarch addresses, in the first instance, two traditions of Dido in his Trionfi: the Virgilian tradition and a separate, anti-Virgilian tradition. ${ }^{6}$ The Virgilian tradition of Dido needs no introduction. To the second, anti-Virgilian tradition, Petrarch alludes twice in the Triumph of Chastity. The first allusion is made near the very beginning, as Petrarch compares himself with other chaste lovers: he says he sees Dido, "ch'amor pio del suo sposo a morte spinse, / non quel d'Enea, com'è 'l publico grido" (TPud., 11-12). ${ }^{7}$ This first rejection of the superficial, publicly accepted Dido is, 
however, insufficient. The issue clearly troubles the progress of the Triumphs, and Petrarch feels compelled to repeat and expand it soon afterwards, again making a point of literary history by once again dismissing common opinion as ignorant. Among the followers of Chastity's triumphal car, he sees Dido:

Poi vidi, fra le donne pellegrine, Quella che per lo suo diletto e fido Sposo, non per Enea, volse ire al fine:

Taccia il vulgo ignorante! Io dico Dido, Cui studio d'onestate a morte spinse, Non vano amor, com è il publico grido.

$$
\text { (TPud. , } 1.154-59)
$$

This anti-Virgilian tradition runs as follows: Dido lived more than 300 years after Aeneas. A fugitive from Tyre, where her husband Sichaeus had been assassinated by her brother Pigmaleon, she cunningly fled to the site of Carthage. Equally cunningly, she bought land for the city, which she established until, importuned by a local king, and by her own people who wanted her to marry, she committed suicide, having preferred to preserve her chastity

Petrarch passionately holds to this version, attested by Macrobius among others, across a variety of writings: in the Trionfi (as we have seen), in the Africa (as we shall see), and in his Epistulae Seniles. ${ }^{8}$ There, 
having listed the authorities for the alternative version, he goes on thus: "But why I am I seeking authorities for something so clear? For who, except some of the multitude, who anywhere I ask, is so uneducated as not to know that the story of Dido and Aeneas is fictitious, and that it has gained the status of truth among men, eager not so much for truth as for beauty?" ${ }^{9}$

That Petrarch should accuse Virgil of lying poses a conundrum, given what has been said above about Petrarch's veneration for classical literature, and his easily attestable reverence for Virgil in particular. ${ }^{10}$ The very accusation of lying in the seniles is, for example, itself made in the context of a much larger, deeply reverential interpretation of the Virgil's epic (along the standard lines of an allegorical

Bildungsroman).${ }^{11}$ Petrarch introduces his discussion by describing the Aeneid as a "divine work," the "very first and foremost" of works for those who "sip from the Castalian spring."12 Unravelling the conundrum leads us, I think, to one of the real motors of the Trionfi, in which Virgil's text must be questioned in order that Virgilian ideology be preserved. Petrarch is accusing Virgil of lying only in order to preserve the text of the Aeneid for a higher truth, inaccessible to the ignorant vulgus. In the Seniles letter Petrarch does not explicitly answer the question he poses. Why, he asks, should Virgil have 
used so chaste a woman for a narrative in which she was to play to role of one "obedient to lustful love." He refuses, however, to give an answer: "one can ask, but doubt will still remain. What I feel or think about this, because you will hear it from me personally, I omit here so as not to pile up more here."13

Petrarch never says explicitly why he so favours the version of Dido that contradicts the version of the "divine" Virgil. ${ }^{14}$ Here I suggest an answer: Petrarch attacks Virgil in order to save Virgil. He questions Virgil's narrative, that is, at the very point at which it was most vulnerable to a third Dido tradition, that derived from of Ovid's deeply sympathetic representation of Dido in Heroides $7 .{ }^{15}$ This tradition, with a powerful later medieval development, is implicitly hostile to Aeneas and, so, to the imperial project that Aeneas pursues. By removing Dido from the narrative, Petrarch removes the most powerful stain on Aeneas' reputation; he even goes so far, indeed, as to remove Aeneas from Carthage altogether: he cites Augustine to the effect that Aeneas never went to Carthage at all. ${ }^{16}$

This interpretation from silence might have a superficial plausibility, but can offer no more than that. What sustains it, however, are major Petrarchan rewritings of the Aeneas story that reinstate the Dido figure in a different guise. Precisely by removing Dido 
from the narrative of Roman/Punic relations, Petrarch leaves himself open to reinsert a Dido figure that deserves to be abandoned by a new, improved Aeneas. This Dido is more in keeping with the Dido regarded by some interpretative traditions as the personification of lust. ${ }^{17}$ This reinstatement of a Dido figure is most obvious in the Africa, the Latin, Virgilian epic, begun in the late 1330s, which Petrarch continued to write until and beyond the putative first period of the Trionfi (1352), but never published. It is also true of the second chapter of the Triumphus Cupidinis. Both these rewritings, or at least recollections, of the Aeneid offer a reprise of Virgil's work by laying a more recent amatory encounter, between Scipio's North African general Massinissa and the Nubian queen Sophonisba, over the classical narrative.

In the Africa this overlaying occurs in the context of an extended epic narrative of the Second Punic War, in which a new North African Dido (i.e. Sophonisba) threatens to impede the progress of Scipio in his campaign against Hannibal. Massinissa, a North African king co-opted to the Roman side, falls in love with the defeated Nubian queen Sophonisba, who betrays her husband Syphax in marrying Massinissa, and also persuades Syphax to betray the Romans. Scipio intervenes to dissuade Massinissa from succumbing to a vortex of sensual desire. 
After a violent internal struggle, torn between his desire for Sophonisba and his fidelity to Scipio, Massinissa sends poison to Sophonisba, who drinks it. ${ }^{18}$

Once again, this narrative is prepared for by carefully dismissing the Virgilian account of Dido: early on in the poem a minstrel praises Dido and rejects the account of a later poet (i.e. Virgil) who, incredibly, would describe her as lustful. ${ }^{19}$ Once again, however, this is no dismissal of the imperial project of the Aeneid: very soon after that dismissal of Virgil's Dido, Scipio's general Laelius praises Aeneas as the first and founding Roman hero. He does so in a very brief summary of the Aeneid that omits any mention of Dido whatsoever (3.458$518 ; 3.615-40) .{ }^{20}$ This initial alignment with the Aeneid (extracting Dido yet insisting on Aeneas' greatness) prepares the way for the much larger narrative palimpsest of the Massinissa/Sohphonisba story.

Petrarch devotes the whole of Book 5 of the Africa to the Massinissa/Sophonisba episode. Having extracted Dido from the narrative of the Aeneid, Petrarch reinserts her by insistent verbal and narrative connections between Sophonisba and Dido: Sophonisba marries her lover in an illicit marriage; she betrays the memory of her first husband and feels guilty in nocturnal visions (Africa, 5.257-72; cf. Virgil, Aeneid 4.457-73); her actions arouse the power of Rumour; ${ }^{21}$ she threatens the Roman 
imperial mission; she commits suicide (Africa, 5.771-3; cf. Virgil, Aeneid 4.663-65); she curses the Scipio with the malediction of a lonely death before she dies. ${ }^{22}$ Some of these narrative parallels with Virgil's Dido are underscored by very explicit verbal echoes. In all this Scipio plays the role not so much of Aeneas, but of the exegete of the Aeneid, wholly untouched by erotic passion. Just as a long tradition of exegesis had interpreted Dido as the lust that youthful masculinity must experience and overcome, ${ }^{23}$ so too does Scipio dissuade Massinissa from submission to erotic passion (5.386-438; 5.519-73). Or, rather than playing the exegete, Scipio plays the role of the mature Aeneas who has learned the lessons of chastity, instructing his alter ego Massinissa. ${ }^{24}$ Scipio as Aeneas in this text is entirely sealed off from any erotic engagement whatsoever.

Massinissa heeds his advice and sends to Sophonisba the poison with which she must kill herself. If Scipio and Massinissa divide the role of Aeneas, Sophonisba plays the role of a very fully realised Dido, but one much more unequivocally and maliciously obstructive to the Roman imperial mission, and one whose destruction does nothing to stain the reputation of the Roman imperialist. The Dido narrative has been reembedded in a narrative that overlays the Aeneid, but 
this time in such a way as wholly to justify the Roman response. So far from ending with any critique of the Aeneid or of Aeneas, the Africa ends with the imperial triumph of Scipio, followed by his captives. Second only to Scipio, at the end of the poem Massinissa, the coopted African who has made the right choices, is the biggest winner. On the way back to Rome the poet Ennius, who has accompanied the general Scipio, predicts Rome's future greatness and predicts the laureation of the future Petrarch, who will sing the laureation of the victorious Scipio.

What of the same narrative in the Trionfi, begun, perhaps, in 1352, with the Africa still unfinished and unpublished? The Triumphs of both Cupid and Chastity seem to have been written as a pair. Their most frequent procedure is one of allusion; thrice, however, they pause to develop a larger narrative. The first of these exceptional narratives is that of Massinissa and Sophonisba, whom Petrarch meets in his vision of Cupid's triumph in what is very much a direct continuation of their story in the Africa. Just as Massinissa in the earlier text desires an escape from life to be joined with his lover, where "in darkest Hell / [as] one shade...Then shall we go in tears / with matching steps" (5.718-22), so too in the Trionfi is Petrarch drawn to "due che a mano a mano / passavan dolcemente lagrimando" 
(TPud., 2.5-6). Once again, in the prison of apparent subjection to Cupid, Massinissa in fact reiterates his real subjection neither to Sophonisba, nor to Cupid, but instead to Scipio, in a series of paradoxes: "Lei, ed ogni mio bene, ogni speranza / perder elessi, per non perder fede" (TPud., 2.68-9). This scene is deeply connected to the meeting of Dante with Paolo and Francesca in Inferno $V$, through situational resemblances and verbal echoes. But while Dante's Francesca continues to reiterate the painful moral ambiguity through which she ends in Hell, Massinissa, by contrast, instead declares his continuing commitment to Scipio's judgement that guided him on earth, as still in death. Francesca issues forth from "la schiera ov" è Dido" (Inferno 5.85), while Massinissa insists on his triumph over the new Dido under direction from his general Scipio:

Grande giustitia agli amanti è grave offesa; Però di tanto amico un tal consiglio Fu quasi un scoglio a l'amorosa impresa.

$$
\text { ( TPud. }, 2.52-4)
$$

Whereas Dante falls at the end of Inferno 5, overwhelmed both by his sympathy for Francesca and by the force of divine judgement, here it is instead Massinissa who delivers the positive verdict on his earthly rejection of Sophonisba. And that rejection is driven by fidelity to the imperial project. 
Once again, then, as in the Africa, Dido is extracted from the Aeneid only to be put right back as the woman whose suicide is never less than a deserved command from the Roman general. In order to preserve the Aeneas/Scipio figure from all taint of passion, the Aeneid requires some rearrangement. In order to save Virgil, Virgil must be rewritten.

The Massinissa/Sophonisba episode (83 lines) is one of the few large interruptions to the habitual, allusive procedure of the Triumph of Cupid. The Massinissa episode, however, not only interrupts the narrative procedures of the Triumphus Cupidinis; it also disrupts and profoundly realigns the Ovidian premises of a Cupidian triumph. Petrarch's triumph of Cupid unquestionably begins by evoking the opening of Ovid's Amores (1.2), ${ }^{25}$ which glories in the comic paradoxes of the most powerful being led in triumph as Love's captives. In Petrarch's scene, too, Caesar leads the first group of Cupid's captives, a group of emperors. Throughout Ovid's Amores, however, the paradox of the triumphal form being used to disrupt triumphal ideology is sustained. Petrarch, by contrast, introduces a powerful, anti-Ovidian pressure, by taking the disciplines of empire entirely seriously, and giving them priority above those of Cupid. Massinissa might be part of Cupid's train, but his fate is determined not by 
obedience to Cupid so much as by his fidelity to the imperial ambitions of his Roman general Scipio. Petrarch, astonishingly, declares his own intent in the Africa as "utterly to destroy the cursed race of Africa" (1.7477), ${ }^{26}$ in order, as Scipio's father tells him, that the Carthaginians should learn again to know the "lash" of their mistress Rome (1.260). ${ }^{27}$ So too in the Trionfi does the Ovidian Cupid learn to know the lash of imperial discipline. A powerful and explicitly Ovidian elegiac tradition is invoked only to be profoundly realigned. This realignment determines the pattern of battle and the triumphal route in the Triumph of Chastity, even before we witness those events. The sequence of one triumphal figure following another in the Trionfi is ostensibly a dialectical movement: one apparently invincible figure is yet defeated by the next: Love by Chastity; Chastity by Death; Death by Fame and so on. ${ }^{28}$ In fact, however, this dialectic is, in the relation of the first two triumphs, neutralised by the rewriting of Dido in the Triumph of Cupid. ${ }^{29}$ Once Cupid is defeated from within his own triumph, there can be no doubt of the result of the encounter between Laura and Cupid in the following Triumphus Pudicitiae. Laura is, indeed, likened primarily to none other than scipio in her moment of victory. Cupid falls, and

$$
\text { Non fu il cader di subito si strano }
$$


Dopo tante victorie ad Haniballe,

Vinto a la fin dal giovene romano.

( $\underline{\text { TPud. }}$, 97-9)

Laura's victory does not so much as challenge as

reiterate the central victory in the Triumph of Cupid:

Scipio, and, by association, an imperialist ideology,

triumph in both. ${ }^{30}$ So too is Laura's triumphal journey in

the Triumphus Pudicitiae determined by fidelity to both

Aeneas and Scipio. The struggle between Cupid and Laura

takes place on Cupid's island Cyprus; having won, Laura

returns to Italy, landing first in the bay of Naples, and

moving finally to the Capitol in Rome. En route, she

passes two, and only two mentioned sites in sequence: the

cave of the Cumean Sybil, whence Aeneas entered Hell, and

the village of Scipio's exile, Linterno. The small

village is referred to thus:

In cosi angusta e solitaria villa

Era il grand 'uom che d'Affrica s'appella,

Perché prima col ferro al vivo aprilla.

(TPud.

Scipio's joining the triumph of Laura is described in a paradoxical formulation: born "sol per triumphi e per imperii," Scipio is not displeased "'il triumpho non suo seguire" ( $\underline{\text { TPud. }}, 175-7)$. But this paradox is underwritten by another, much more terrible paradox embedded in the last line of the tercet just cited. Scipio, the champion 
of chastity, is described as Scipio Africanus because he attacked Africa first in brutally phallic manner: "perché prima col ferro al vivo aprilla" ( observation here is that Petrarch's structure is not paradoxical at all: despite the apparent, Ovidian tension generated by amatory players adopting military forms of a triumph, the real commitment here all along is to the military and imperial achievement of Aeneas and Scipio, to opening Africa alive with the sword. Ovid's amatory poetry sets the asymmetries of love and war, of Ovidian elegy and heroic poetry, in constant and playful tension. In the Trionfi, by contrast, erotic desire is unequivocally disciplined, however painfully, by the needs of imperial domination. Africa must know the "lash" of her imperial Roman mistress.

II

We began by recalling the very powerful and still vibrant traditions by which Petrarch is hailed as the first Renaissance man, by virtue particularly of his capacity for what Thomas Greene calls "heuristic imitation," itself a code for a truly historical consciousness. What kind of historical consciousness is possible under the conditions I have just described? Ovidian elegy often serves as an opening of memory into 
spaces dominated by the apparently unassailable remembrance of epic: Ovid's Dido in the Heroides, for example, works into the chink in Aeneas' reputation in the Aeneid, and exposes a large area for reinterpretation. The voice of a single, suffering woman of labile memory pits itself, not unsuccessfully, against the voice of the Virgil's divine Muses, who recount the apparently unassailable narrative of imperial foundation, often citing the gods themselves. Given Petrarch's disciplining of Ovid as just described, what spaces for memory does that leave Petrarch as poet? Does the Trionfi provide evidence of a truly historical consciousness?

Twentieth century scholarship on Petrarch offers many instances of denial that Petrarch has any interest whatsoever in politics; as a true humanist, he is solely concerned with moral ideals. ${ }^{31}$ It seems to me, by constrast, that Petrarch places himself very squarely as a poet behind the imperial project of Scipio. This is most obviously true of the Africa, where Scipio's father, in a dismissal of earthly fame, confidently predicts to Scipio Affricanus that a second Ennius, not inspired by hope of reward but only by "reverence for high-souled deeds," will one day sing their glory (2.588). ${ }^{32}$ Likewise, at the end of the poem, Ennius himself recounts a dream to the victorious Scipio of his (Ennius') encounter with Homer. Together, Ennius and Homer literally foresee the 
young Petrarch, as prepares himself for poetic glory: Petrarch will "climb the Capitol," and return thence "flanked by the company of Senators," with "brow girt by the glorious laurel wreath" (9.323-31). ${ }^{33}$ The intimate connection between state power and poetic enterprise is, clearly enough, expressed in the single motif of the triumphal laurel that crowns both imperial victor and poet. This future Petrarch will be the "fruit of a womb long barren" (9.340), a reference to Rome's long period of decadence from its imperial glory that will be revived in memory by Petrarch.

The Africa, then, presents a poet full square behind the imperial enterprise. What of the Trionfi, where there is, initially at any rate, a greater tension between the demands of empire and of love? On the face of it, the story is the same: even in the description of cupid's triumphal chariot, Petrarch marvels at the recuperation of ancient dignity, to which he is unaccustomed "per lo secol noioso in ch'i' mi trovo, / vòto d'ogni valor" (TCup., 1.17-8). This longing for a renaissance of Roman state glory finds fuller expression at the end of the Triumph of Chastity. Here Laura imitates not only Scipio in deposing her trophies in a temple, but also evokes Petrarch's own poetic coronation on the Capitol in 1341, when he, too, laid his poetic crown on the altar of the Basilica of st Peter. ${ }^{34}$ 
The perspective of the Trionfi is, however, more complex, and worth pausing over, the better to define the tortured relation between power and poetry, and the intensity of a historical imagination wholly subject to a punishing power. For in the Trionfi Petrarch is a prisoner to love; he does not, as he does in the Africa, have unimpeded access to the historical archive, with the long perspectives of visionary epic, in which he sees, and is foreseen, by his poetic and military heroes. The lines of sight in the Trionfi are, by contrast, determined rather only by the glancing, broken vision permissible in the slow march of triumphal captivity. Here, I would suggest, it is slavery that determines the lines of sight and the intensity of the historical imagination.

Lines 85-184 of the third capitolo of the Triumphus Cupidinis relate the narrative of Petrarch's own captivity. These very powerful lines distort the narrative perspective of the triumphal scene, since the personal memory forces its way, and expands into the processional description of Cupid's passage. Petrarch relates in brief but poignant form the entire history of his love for Laura. This experience is one of humiliation, withdrawal and self-doubt; it is of broken perspectives that produce broken, torn writings (line 117) and language that falls forever short. Above all, it 
recounts an intensely personal experience of subjection and self-division, most powerfully expressed in the set of anaphoric sentences beginning line 151: "Or so come da sé 'l cor si disgiunge;" each of these sentences declares a knowledge in which knowledge is defeated:

So fra lunghi sospiri e brevi risa

$$
\begin{aligned}
& \text { stato, voglia, color cangiare spesso, } \\
& \text { viver, stando dal cor l'alma divisa. }
\end{aligned}
$$$$
\text { So mille volte il di ingannar mi stesso. }
$$$$
\text { So, seguendo 'l mio foco ovunque } e^{\prime} \text { fugge, }
$$$$
\text { arder da lunge, ed agghiacciar da presso. }
$$

So come Amor sovra la mente rugge.

$$
\text { ( TCup. , 3.163-69) }
$$

This experience of the profoundly divided, not to say terrorised self has been taken as crucial evidence for Petrarch's modernity: not only does Petrarch feel historically isolated in time, but he is also capable of inward, subjective division. I have argued elsewhere that this position is mistaken, since the division of self taken to be characteristic of modernity is in fact directly derivable from Ovid, and, as such, is equally available to a long and powerful tradition of European medieval lyric writing. ${ }^{35}$

That said, this moving passage in the Trionfi does signal something distinctive in Petrarch. What is new here is, it seems to me, the tension between this 
fundamentally Ovidian perspective in the context of a deeper commitment to the perspectives of Virgilian, heroic, imperialist poetry. The self is terrorised by the experience of its own division, but that division is not only, in the larger context of the Trionfi, a two-way cut. Petrarch's represented self desires not only its self-sufficiency and integration on the one hand and, at the same time, its union with a relentlessly hostile, infinitely desirable force on the other. The division, in the larger context of the Trionfi, is, instead, a threeway division, between the poles just mentioned and a further, even more powerful and crushing force, that of the need for submission to imperial duty. This triangular division produces a powerful new model for vernacular writing that was to have a very powerful response in the sixteenth century. It also produces a new kind of literary historical attention.

This is a large claim, which might in part be tested by accounting for Petrarch's immense prestige among his sixteenth century followers, who wrote under the regimes of punishing political masters; some of them also wrote as they were actively engaged in imperial missions. ${ }^{36}$ The Petrarchan tradition in England, for example, is held within the contending poles of tormento and consento, to cite the terms of the first Pertarcan sonnet translated, albeit not in sonnet form, into English, by Chaucer. ${ }^{37}$ I 
do not have space to pursue that claim here, but I will end by answering the question about Petrarch's historical consciousness in the Trionfi, by particular reference to the formal properties of this work. Both are determined, I suggest, by Petrarch's subjection to imperial demand. As I have said, the primary formal property of the Trionfi is learned allusion and/or elliptical reference. Each triumphal procession is peopled by figures to the decisive, painful, memorable moments of whose lives Petrarch alludes with learned, brief reference. ${ }^{38}$ Very often the name is withheld, and left for the reader to produce. The reader is thus expected to identify the very first figure seen, the "garzon crudo / con arco in man e con saette a'fianchi" (TCup., 1.23-4), before the friend explicates the reference at line 75 ("Questi è colui che 'l mondo chiama Amore"). Sometimes the name is withheld altogether, leaving the reader to supply proper names where the text gives only pronouns or periphrases, as in this reference to Theseus, Ariadne and Phaedra:

Vedi 'l famoso, con sua tanta lode, Preso menar tra due sorelle morte: L'una da lui, ed ei de l'altra gode.

$$
\text { ( } \underline{\text { TCup }} ., 1.121-23)
$$

Or most often the name is given, but the story withheld, requiring the reader to supply it (e.g. TCup., 1.139-44). In most cases, however, whatever the precise manner of 
allusive, periphrastic reference, the point of the life recalled is a point of pain. Even where the narrative is withheld from a series of names, cries of pain provide the leitmotif for the lives withheld. Thus (the abandoned) Oenone and Menelaus, (the raped and murdered) Hermione, (the suicide) Laodamia, and (the widow) Argia are all very briefly named before their joint cries of pain are recorded:

Odi 'l pianto e i sospiri, odi le strida De le misere accese, che li spirti Rendero a lui che 'n tal modo gli guida.

$$
\text { (TCup. , 1.145-7) }
$$

This allusive, periphrastic listing of captive figures has in fact been the main source of complaint about the Trionfi. Critics have found the work interesting only at those moments where procession and allusive listing give way to action. ${ }^{39}$ This complaint is superficial; it misses the point that brevity of allusion is the formal result of the narrator's subjection. Subjection itself provokes the desire to know analogous stories as its consolation; it also determines the brevity of time permitted to know them. The conclusion of Cupid's Triumph expresses both these points, in which Cupid's captives find themselves, at the end of their procession, in a dark prison. The incarceration provokes the desire for impossible escape, a desire that is consoled only by knowing the stories of 
fellow sufferers. Cupid's captives are enclosed within "cosi tenebrosa e stretta gabbia," in which ...pur sognando libertate, l'alma, che 'l gran disio fea pronta e leve, consolai col veder le cose andate.

$$
(\underline{\text { TCup. }}, \quad 4.160-62)
$$

Subjection provokes the desire to know literary history in its most intense moments, but it also determines the brevity of encounter. The slow pace of the procession of captured slaves allows the captive a glance at his fellows, but it also demands the slow but punishing onward pace that leaves the glance unsatisfied. The Triumph ends by making precisely this point, and so accounting for its own formal procedures:

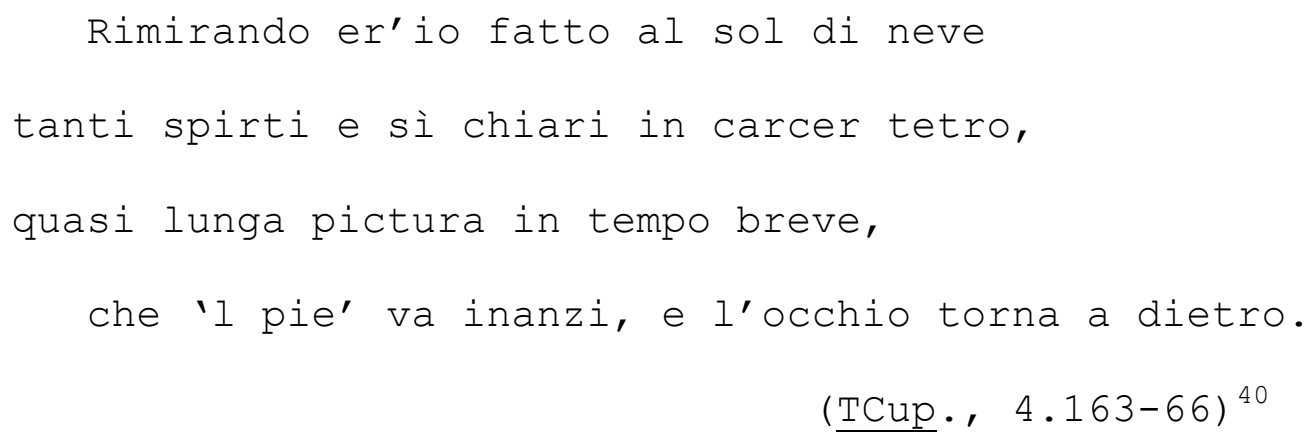

The captive foot is obliged to move forwards in the procession of human trophies, while the eye, inspired precisely by its captivity, looks backwards. The combination of forward step and backward glance limit the eye's time, and so produce allusive, literally glancing reference. The allusions obviously create the need for an 
elite readership that understands them, but the elitism is not what drives this particular formation of literary history. What drives it is the desire for freedom born of elite captivity, and what constrains it is lack of time. The experience of literary history under these conditions is one of exhausting fascination:

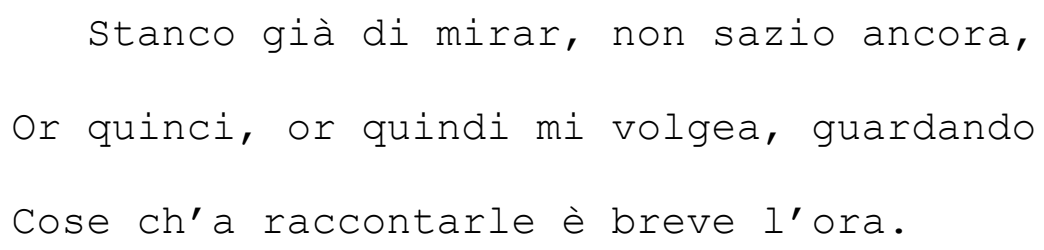

(

This does not seem to me to be characteristic of the historical consciousness so praised by critics who laud Petrarch's humanism. Neither am I certain that this ideal of humanistic philology can ever be more than a wraith, an ideological measure with which to fail other forms of historical consciousness. But in Petrarch's case in the Trionfi, at any rate, the form of historical consciousness is focussed on and directed by its attention to the pain of captives. One could argue that this is because Love's law is itself a-historical and ineluctable, as Petrarch himself says:

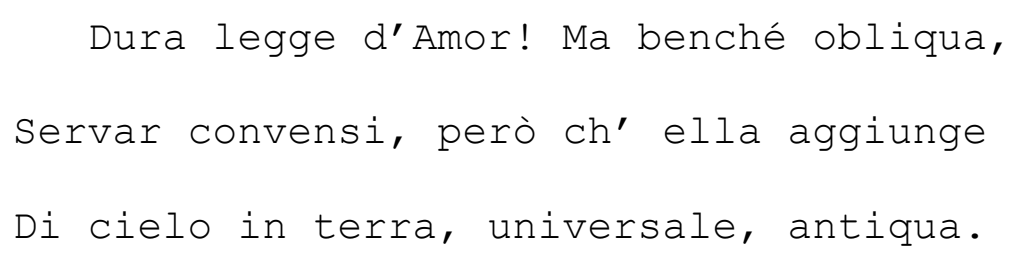


But, as we have seen, there is, by Petrarch's account in the Trionfi at any rate, a force greater than that of Cupid, which is imperial raison d'etat. It too, as represented by Petrarch's reconstruction of Roman forms in the Africa and in the Trionfi, "agguinge / di cielo in terra, universale, antiqua." The reconstruction of Roman forms serves much less the ends of a truly historical consciousness than of instigating the visible sign of a new disciplinary force that must be served, "benché obliqua." 


\section{$\underline{\text { Endnotes }}$}

I am especially grateful to Valeria Finucci for having organized the symposium in honor of Ron witt at which this essay was originally read as a paper. I also aknowledge with gratitude the penetrating comments on the paper offered by Kevin Brownlee and Virginia Cox.

1 Petrarch himself began the tradition, describing himself as poised between two epochs, looking forward and backward; he says this about himself, for example: "Ego itaque, cui nec dolendi ratio deest nec ingnorantiae solamen adest, velut in confinio duorum populorum constitutus ac simul ante retroque prospiciens..." Rerum Memorandarum Libri, ed. Giuseppe Billanovich (Florence: Sansoni, 1943), I.19.4, p. 19. The tradition remained vibrant across the twentieth century. See, for example (to cite only a few celebrated names), Pierre de Nolhac, Petrarque et l'Humanisme, revised edition, 2 vols. (Paris: Champion, 1965; first published 1907), Chapter 1, for the most triumphalist account of Petrarch as "l"initiateur de la Renaissance" (p. 1). Much more 
measured accounts repeat the idea; see, for example Theodore Mommsen, "Petrarch's Conception of the 'Dark Ages" ", Speculum 17 (1942), 226-242, who decares that Petrarch "stands at the very fountainhead of Renaissance thought" (p. 242); and Nicholas Mann, Petrarch (Oxford: Oxford University Press, 1984), who describes Petrarch as "the first modern man" (p. 113); and Paul Oskar Kristeller, "Il Petrarca nella Storia degli Studii," in Petrarca e la Cultura Europea, ed. Luisa Rotondi Secchi Tarugi (Milan: Nuovi Orizzonti, 1997), 7-29, who describes Petrarch as "il profeta e precursore di molte correnti posteriori" and "il primo grande umanista" (p. 7) .

2 Thomas M. Greene, The Light in Troy: Imitation and Discovery in Renaissance Poetry (New Haven: Yale University Press, 1982), Chapters 5 and 6 especially. See also p. 8: "For Petrarch...the intuition of this pathos [of historical solitude] was no longer redeemable; it was tragic. It bespoke not only the impermanence but also the solitude of history. This was a solitude which Petrarch lived out existentially, as estrangement from the ancients who were dearer to him...than all but a few of his contemporaries."

3 Thomas M. Greene, The Light in Troy: "It was he [Petrarch] who first understood how radically classical 
antiquity differed from the Christian era; ...he who understood more clearly the philological meaning of anachronism" (pp. 29-30).

4 Petrarch continued to work on and add to the Trionfi until the very end of his life in 1374; when he began the series is a matter of conjecture. The traditional dating is Spring 1352; see Francesco Petrarca, Trionfi, Rime Estravaganti, Codice degli Abbozzi, ed. Vinicio Pacca and Laura Paolino (Milan: Mondadori, 1996), p. 44. All citations are taken from this edition. For the counter view (that the Trionfi were begun in 1340-44, before the death of Laura in 1348, see, for example, Ernest Hatch Wilkins, Life of Petrarch (Chicago: University of Chicago Press, 1961), pp. 22, 31-2, 47-8. For the plausible theory that the first two triumphs, those of Cupid and Chastity, were written as a pair, see Ernest Hatch Wilkins, "The First Two Triumphs of Petrarch," Italica 40 (1963), 7-17. For Petrarch's first stay with the Visconti from summer 1353, in Milan, see Wilkins, Life of Petrarch, pp. 129-142.

5 See, for example, Anthony Grafton and Lisa Jardine, From Humanism to the Humanities: Education and the Liberal Arts in Fifteenth and Sixteenth Century Europe (London: Duckworth, 1986); Stephanie H. Jed, Chaste Thinking: The Rape of Lucretia and the Birth of Humanism 
(Bloomington, Ind.: Indiana University Press, 1989); and David Wallace, Chaucerian Polity: Absolutist Lineages and Associational Forms in England and Italy (Stanford University Press, 1997), the last of which has particular bearing on the present argument, especially Chapter 10 . 6 For the three principal classical traditions of Dido (i.e. the Virgilian Dido; the "historical Dido"; and the Ovidian Dido) alive in the later medieval and Early Modern periods, see Marilyn Desmond, Reading Dido: Gender, Textuality and the Medieval "Aeneid", Medieval Cultures 8 (Minneapolis: University of Minnesota Press, 1994), Chapter 1 .

$7 \quad$ All citations from the Tronfi are taken from Petrarca, Trionfi, ed. Pacca and Paolino. Further citations will be given parenthetically in the text by triumph, capitolo if relevant, and line number.

8 For the late antique sources of the "Historical Dido," see Desmond, Reading Dido, pp. 24-33 and further references; see also Petrarca, Trionfi, ed. Pacca and Paolino, pp. 228-9, who, in addition to citing the loci for Petrarch's other references to the tradition of the "Historical Dido," cite the relevant Latin text of the Epistulae Seniles 4.5 discussed below.

9 Translation cited from Francis Petrarch, Letters of Old Age (Rerum senilium libri I-XVIII), 2 vols., translated 
by Aldo S. Bernardo, S. Levin, and Rita A. Bernardo (Baltimore: Johns Hopkins University Press, 1992), 4.5, pp. 139-51 (at p. 147).

10 For Petrarch's reverence for Virgil, see de Nolhac,

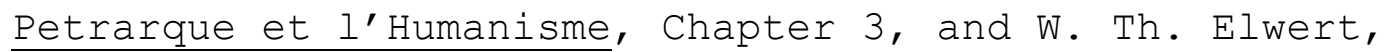
"Vergil und Petrarca," in his Europäische Wechselbeziehungen (Wiesbaden: Steiner, 1986), 21-31 (pp. 22-3 for Petrarch's praise of Virgil, and pp. 26-8 for specific parallels between the Aeneid and Africa). 11 For the tradition of this allegorical interpretation, see Christopher Baswell, Virgil in Medieval England: Figuring the 'Aeneid' from the Twelfth Century to Chaucer (Cambridge: Cambridge University Press, 1995), Chapter 3. 12 Petrarch, Letters of Old Age, trans. Bernardo, Levin, and Bernardo, 4.5, p. 140 .

13 Petrarch, Letters of old Age, trans. Bernardo, Levin, and Bernardo, 4.5, p. 148.

14 Boccaccio, who was torn between these different traditions, does offer an explanation of sorts(that Virgil, with poetic license, drew on a convenient figure for Aeneas' lover, despite the historical impossibility). See Craig Kallendorf, "Boccaccio's Dido and the Rhetorical Criticism of Virgil's Aeneid," Studies in Philology 82 (1985), 401-15 (p. 413). 
15 For which see especially Desmond, Reading Dido, pp. 33-45; and for the power of this tradition, sympathetic to Dido, in later medieval writing, pp. 46-55. See also Peter Dronke, "Dido's Lament: From Medieval Latin Lyric to Chaucer," in Kontinuität und Wandel: Lateinische Poesie von Naerius bis Baudelaire, ed. Ulrich Justus Stache, Wolfgang Maaz and Fritz Wagner (Hildesheim: Weimannsche, 1986), 364-90. 16 Petrarch, Letters of old Age, trans. Bernardo, Levin, and Bernardo, 4.5, p. 147. The reference is to Augustine, Confessions, I.13, 22 .

17 See Desmond, Reading Dido, Chapter 2, and Baswell, Virgil in Medieval England, p. 116. 18 Petrarch produced three versions of this narrative, in the De viris illustribus, the Africa and the Trionfi. The sequence in the De viris, inserted into the second redaction (1341-43) can be found in Francesco Petrarca,

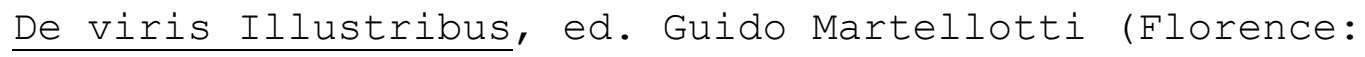
Sansoni, 1964), in "The Life of Scipio," at pp. 227-237. For a descriptive account of the three versions, see Aldo S. Bernardo, Petrarch, Scipio and the "Africa" (Baltimore: Johns Hopkins University Press, 1962). A more penetrating account of the difference of emphasis in these three versions can be found in Johannes Bartuschat, "Sophonisba e Massinissa. Dal Africa e dal De viris ai 
Trionfi," in Petrarca e i suoi lettori, ed. Vittorio Caratozzolo and George Güntert, Memoria del Tempo 18 (Ravenna: Longo, 2000), 109-41.

19 All translations of the Africa are drawn from Petrarch"s "Africa", translated by Thomas G. Bergin and Alice S. Wilson (New Haven: Yale University Press, 1977). They have been checked against the Latin text, which can be found in Francesco Petrarca, L'Africa, ed. Nicola Festa, Edizione Nazionale delle Opere di Francesco Petrarca, 1 (Florence: Sansoni, 1926). The Bergin/Wilson translation is in fact a very loose. I cite both the Festa edition and the Bergin/Wilson translation by book and line number; where I cite both they are in the order of Festa followed by Bergin/Wilson (here 3.424-7, and $3.534-37)$

20 Aeneas is described as escaping Troy and sailing to Italy with reputation unstained: "...unus / Integer enavit sine crimine" (Africa, ed. Festa, 3.497-8). The passage where we would expect mention of Dido reads thus: "...et [Aeneas] passus terra casusque tremendos / Erroresque vagos et mille pericula ponti / Impiger Ausonias tandem tamen attigit oras" (Africa, ed. Festa, 3.505-7). 21 Compare Petrarch, Africa, "Publica finitimas subito perlabitur urbes / Fama gradu" (5.273-4), with Virgil, 
Aeneid, "Extemplo Libyae magnas it Fama per urbes" $(4.173)$.

22 Compare Sophonisba's curse on Scipio: "...sint ultima vite / Tristia, et eximiis sua Roma ingrata tropheis / Exul ut a patria deserto in rure senescat / Solus" (Petrarch, Africa, 5.748-51), with Dido's curse on Aeneas: "...nec, cum se sub leges pacis iniquiae / Tradiderit, regno aut optata luce fruatur, sed cadat ante diem mediaque inhumantus harena" (Virgil, Aeneid, 4.61820) .

23 See, Desmond, Reading Dido, Chapter 2; for an example of such a reading, see the commentary attributed to Bernard Sylvestris, The Commentary on the First Six Books of the "Aeneid" Commonly Attributed to Bernard Sylvestris, ed. Julian Ward Jones and Elizabeth Frances Jones (Lincoln, Nebr: University of Nebraska Press, $1977)$.

24 Guido Martellotti points out parallels between the tears of Massinissa in Book 5 of the Africa and what Petrarch takes to be the tears of Aeneas in Aeneid 4; see his essay "Lagrime di Enea," in his Scritti Petrarchesci, ed. Michele Feo and Silvia Rizzo (Padua: Antenore, 1983; first published 1945), 44-49. 25 For which see Guido Martellotti, "Il Triumphus Cupidinis in Ovidio e nel Petarca," in his Scritti 
Petrarcheschi (Padua: Antenore, 1983), 517-24; and

Richard C. Monti, "Petrarch's Trionfi, Ovid and Virgil," in Petrarch's "Triumphs": Allegory and Spectacle, ed. Konrad Eisenbichler and Amilcare A. Iannucci, University of Toronto Italian Studies 4 (Ottawa: Dovehouse Editions, $1990), 11-32$.

26 Petrarch, Africa: "Ipse ego non nostri referam modo temporis acta, / Marte sed Ausonio sceleratus funditus Afros / Eruere est animus nimiasque retundere vires" $(1.53-55)$.

27 Petrarch, Africa: "Experiere iterum et dominam per verbera nosces" (1.188).

28 For the dialectical structure, see Leo Spitzer, "Zum Aufbau von Petrarca's Trionfi," in his Romanische Literatur-Studien, 1936-56 (Tübingen: Niemeyer, 1959), 614-23 (esp. pp. 615-6).

29 The neutralisation of the apparent dialectic between triumphs is, for different reasons, also noticed by Marguerite Waller, Petrarch's Poetics and Literary History (Amherst: University of Massachusetts Press, 1980), 114

30 For descriptive accounts of the relations between Laura and Scipio in Petrarch's works, see Aldo S. Bernardo, Petrarch, Laura, and the "Triumphs" (Albany: 
State University of New York Press, 1974). See also Petrarch, Canzoniere, no. 186.

31 This reading of the Africa stands opposed to the humanist readings that would deny its interest in imperial projects, and would insist instead on its concentration on moral virtue. Thus the two main lines of interpretation since the fifteenth century have been either that the Trionfi offer a moral allegory (the fifteenth-century tradition of interpretation), or that it is intensely focussed on passionate individual histories (the Romantic position). For the history of reception, see Bernardo, Petrarch, Laura and the "Triumphs" pp. 88-9. In the twentieth-century both traditions have continued, each repressing a politicised reading. De Nolhac, for example, declares that "Les races, les nations, le développment des empires" have little interest for Petrarch: "l'individu seul le passione." What Petrarch seeks in classical narrative is "le plus puissant ressort de perfectionnement moral" (De Nolhac, Petararque et l'Humanisme, 2.9). Guido Martellotti agrees: "Ciò che per Virgilio era il compito fatale di fondar Roma, per Dante e il Petrarca era il dovere d'ogni uomo di levarsi sulla passione d'amore per seguire laudabile via e fruttuosa" ("Lagrime di Enea," 49). Perhaps some of these "humanist" reclamations of 
Petrarch were a way of preserving him from fascist readings in a fascist, or recently fascist Italy. Certainly Petrarch would seem to have been enlisted in an imperialist cause in a fascist Italy. See, for example, the dedication to Africa, ed. Festa: "Alla maestà Vittorio Emmanuele III Re d'Italia questo volume che inizia col poema della vittoria mediterranea di Roma l'edizione nazionale delle opere di Francesco Petrarca è dedicato." Festa's monograph on the Africa (Saggio sull" "Africa" del Petrarca (Palermo: Sandron, 1926)) was also published in 1926; in it he argues thethe Africa should be the "great national poem, composed in that marvellous "lingua nostra" which passes as a dead language only among the ignorant and among the presumptuous mass that inhabits the limbo of demi-culture" (cited in Bernardo, Petrarch, Scipio and the "Africa", p. 192). Aldo Bernardo seems to agree with the "humanists" who depoliticise Petrarch (he approvingly cites the passage from de Nolhac cited above), but with a particular concept of moral virtue and its relation to imperial conquest; the point of the Massinissa/Sophonisba episode in the De viris, he argues, "lies in the new dimension it gives Scipio: not only is he a leader of men and nations, but a savior of souls;" in Book 6 "the moral order is once again restored and the African campaign is seriously 
resumed" (Petrarch, Scipio and the "Africa", p. 30). He later, however, becomes explicit about his admiration of African subjection to Roman rule. The Massinissa/Sophonisba episode is "an example of Roman magnanimity overcoming the shadows and ignorance under which other peoples laboured. Both lovers descended from African races; both were weak in resisting passion" ( $p$. 151); when the "dark" Sophonisba descends to Tartarus, "one feels that she has joined her proper element since there is no resisting or escaping the inexorable enlightenment that Rome is fated to spread throughout the world" (p. 153).

32 Petrarch, Africa: "In quod eum studium non vis pretiumve movebit, / Non metus aut odium, non spes aut grata nostri; / Magnarum sed sola quidem admiratio rerum, / Solus amor veri" (2.451-54).

33 Petrarch, Africa: "...insigni florentia lauro / Tempora descendens referat comitante senatu" (9.240-41).

34 For specific parallels, see Trionfi, ed. Pacca and Paolino, 263. For Petrarch's very explicit connection between the poetic and military crowning, see W. Suerbaum, "Poeta laureatus et triumphans: Die Dichterkrönung Petracas und sein Ennius-bild," Poetica 5 (1972), 293-328. For the parrallel between Laura's and Petrarch's crowning, see p. 324 note 64 . 
35 James Simpson, Reform and Cultural Revolution, 1350-

1547 (Oxford: Oxford University Press, 2002), Chapter 4. 36 For which see the interesting but sometimes forced readings in Roland Greene, Unrequited Conquests: Love and Empire in the Colonial Americas (Chicago: University of Chicago Press, 1999).

37 This argument has been made for England by Simpson, Reform and Cultural Revolution, Chapter 4. For the Chaucerian critique of Petrarchan poetics, see David Wallace, "'Whan she translated was': A Chaucerian Critique of the Petrarchan Academy," in Literary Practice and Social Change in Britain, 1380-1530, ed. Lee Patterson, The New Historicism 8 (University of California Press, 1990), 156-215. The terms "tormento" and "consento" are the critical rhyme words in Petrarch, Canzoniere, 132, the source of Troilus' lyric in Chaucer's Troilus and Criseyde 1.400-20.

38 Critics customarily complain about abbreviation in the Trionfi; for a more sympathetic and accurate account of the extreme compression of style in these lists, and throughout the Trionfi, see Claudia Berra, "La Varietà Stilistica dei Trionfi," in I "Triumphi" di Francesco Petrarca, ed. Claudia Berra (Milan: Cisalpino, 1999), 175-218 (esp. pp. 186-7 and 192-3). See also Massimo Verdicchio, "The Rhetoric of Enumeration in Petrarch's 
Trionfi," in Allegory and Spectacle, ed. Eisenbichler and Iannucci, 135-46.

39 For critical complaint about the lists, see Waller, Petrarch's Poetics and Literary History, 128-9.

40 For the sources of the "lunga pictura," both literary and Visual, see Carlo Vecce, "La 'Lunga Pictura:' Visione e Rappresentazione nei Trionfi," in I "Triumphi" di Francesco Petrarca, ed. Berra, 299-315 (esp. pp. 309-15). 